\title{
Catalytic Activities of Perovskite-type $\mathrm{LaBO}_{3}(\mathrm{~B}=\mathrm{Fe}, \mathrm{Co}$, Ni) Oxides for Partial Oxidation of Methane
}

\author{
Myung-Jin Lee, Jong-Ho Jun, ${ }^{\dagger}$ Jin-Seung Jung, ${ }^{\ddagger}$ Yong-Rok Kim, ${ }^{\S}$ and Sung-Han Lee \\ Department of Chemistry, Yonsei University, Wonju 220-710, Korea. *E-mail: shl2238@dragon.yonsei.ac.kr \\ ${ }^{\dagger}$ Department of Applied Chemistry, Konkuk University, Choongju 380-701, Korea \\ Department of Chemistry, Kangnung National University, Kangnung 210-320, Korea \\ ${ }^{\S}$ Department of Chemistry, Yonsei University, Seoul 120-749, Korea \\ Received April 22, 2005
}

Key Words : Lanthanum-transition metal perovskite oxides, Partial oxidation of methane

Direct conversion of methane to $\mathrm{C}_{2}$-hydrocarbons via oxidative coupling reaction has received a great deal of attention for the last twenty five years because the reaction has been recognized as a promising route for the production of ethylene from natural gas. ${ }^{1,2}$ However, the process is considered to be economically unfeasible because the yield of ethylene produced in the reaction is less than $25 \%$. In recent, it has been proposed that the disadvantage may be overcome by integrating with processes involving endothermic reactions such as cracking of ethane to ethylene and steam reforming of methane to synthesis gas and the heat of the exothermic coupling reaction can be alternatively used to generate electricity. ${ }^{3}$

An interesting potential application of perovskites as catalysts is their use for redox reactions. Lanthanum-transition metal perovskite oxides $\left(\mathrm{LaBO}_{3}\right)$ are proved to be effective catalysts for the catalytic oxidations of hydrocarbons, $\mathrm{CO}$, and ammonia and considered to be promising materials for application as electrode materials in solid oxide fuel cells. ${ }^{4-8}$ There are few reports on the application of $\mathrm{LaBO}_{3}$ oxides to the catalytic partial oxidation of methane. Tagawa et al. ${ }^{6}$ found that the $\mathrm{LaAlO}_{3}$ catalyst prepared by the mist decomposition method is highly active and selective for the oxidative coupling of methane and proposed that an amorphous phase of $\mathrm{LaAlO}_{3}$ is responsible for the catalytic activity. Spinicci et $a l .{ }^{8}$ found that both catalytic activity and $\mathrm{C}_{2}$-selectivity are largely enhanced when $\mathrm{Al}^{3+}$ ion in the $\mathrm{LaAlO}_{3}$ perovskite is substituted with $\mathrm{Li}^{+}$or $\mathrm{Mg}^{2+}$. In the oxidative methane coupling reaction catalyzed by metal oxide, the transfer of oxygen to the surface from bulk or gas phase is very important on its catalytic activity because the abstraction of a hydrogen from methane is caused by an oxygen ion present on the surface of metal oxide catalyst. $\mathrm{LaBO}_{3}$ perovskite oxides may be suitable catalysts for the methane coupling reaction because they are characterized by high mobility of oxygen ions. Actually, the perovskite oxides have received increasing interest in the mixed-conducting ceramic membrane reactor technology for partial oxidation of methane. ${ }^{9}$ In this work, we prepared $\mathrm{LaFeO}_{3}, \mathrm{LaCoO}_{3}$, and $\mathrm{LaNiO}_{3}$ perovskite oxides by using a sol-gel method and examined them as catalysts for the oxidative coupling of methane in the temperature range of 650 to $800{ }^{\circ} \mathrm{C}$ at atmospheric pressure.

\section{Experimental Section}

$\mathrm{La}_{2} \mathrm{O}_{3}$ catalyst was prepared by decomposition of lanthanum nitrate $\left(\mathrm{La}\left(\mathrm{NO}_{3}\right)_{3} \cdot 6 \mathrm{H}_{2} \mathrm{O}\right.$, Aldrich, $\left.>99.9 \%\right)$ in air at 500 ${ }^{\circ} \mathrm{C}$, grounding of the powder, and calcination in air at $850{ }^{\circ} \mathrm{C}$ for $24 \mathrm{~h} . \mathrm{LaBO}_{3}(\mathrm{~B}=\mathrm{Fe}, \mathrm{Co}, \mathrm{Ni})$ catalysts were prepared from citrate precursors. Both the lanthanum nitrate and transition metal nitrate $\left(\mathrm{Fe}\left(\mathrm{NO}_{3}\right)_{3} \cdot 9 \mathrm{H}_{2} \mathrm{O}, \mathrm{Co}\left(\mathrm{NO}_{3}\right)_{2} \cdot 6 \mathrm{H}_{2} \mathrm{O}\right.$, $\mathrm{Ni}\left(\mathrm{NO}_{3}\right)_{2} \cdot 6 \mathrm{H}_{2} \mathrm{O}$, Aldrich, $>99.9 \%$ ) were weighed to yield the metal atomic ratio of $\mathrm{La}: \mathrm{B}=1: 1$ and dissolved in deionized water. The resulting solution was mixed with an aqueous solution of citric acid by fixing at unity of the molar ratio of citric acid to the metal ions. Water was evaporated from the mixed solution at $70{ }^{\circ} \mathrm{C}$ in vacuum until a viscous gel was obtained. The mixture was kept at $100^{\circ} \mathrm{C}$ overnight, ground and finally calcined at $850^{\circ} \mathrm{C}$ for $24 \mathrm{~h}$. X-ray powder diffraction analysis was performed for the catalysts using a Philips PW-1710 diffractometer with Ni-filtered $\mathrm{Cu} \mathrm{K}_{\alpha}$ radiation. The JCPDS powder diffraction file was used to identify the crystalline phases present. BET surface areas were measured by nitrogen adsorption at $-196{ }^{\circ} \mathrm{C}$ with a Quantichrome automatic gas adsorption system. Thermogravimetric (TG) and differential scanning calorimetry (DSC) analyses were performed using a TA Instrument in flowing air $\left(10 \mathrm{~cm}^{3} / \mathrm{min}\right)$ with a heating rate of $10^{\circ} \mathrm{C} / \mathrm{min}$ up to $600{ }^{\circ} \mathrm{C}$.

Catalytic tests were carried out in a continuous flow tubular quartz reactor, $0.8 \mathrm{~cm}$ i.d., employing $200 \mathrm{mg}$ of catalyst. The feed flow rate of reaction mixture at ambient condition was $\mathrm{CH}_{4} / \mathrm{O}_{2} / \mathrm{He}=8 / 2 / 10 \mathrm{~cm}^{3} / \mathrm{min}$. The reaction was investigated in the temperature range of $650-800{ }^{\circ} \mathrm{C}$ after in situ pre-treatment of the catalysts in a flow of $\mathrm{O}_{2}(20 \%) / \mathrm{He}$ mixture at $800{ }^{\circ} \mathrm{C}$ for $1 \mathrm{~h}$. The details of kinetic measurements are described in the previous paper. ${ }^{2}$ To get an information about the chemical species adsorbed on the catalyst surface, FT-IR (Fourier-transform infrared) spectroscopy analysis was performed by using an infrared cell as described in the literature. ${ }^{10}$ The IR cell was made of quartz tubing with $10 \mathrm{~cm}$ length and $3.0 \mathrm{~cm}$ diameter, heating coil was wound around the middle of the cell to control the reaction temperature, two turns of copper cooling coils were placed around each end of the cell, and $\mathrm{Zn}-\mathrm{Se}$ windows were attached to both ends of the cell. For the 
in situ IR spectroscopy analysis, the self-supported disk of $\mathrm{LaFeO}_{3}$ was made by compressing the powder $(50 \mathrm{mg})$ at $3 \mathrm{t} / \mathrm{cm}^{2}$ and the $\mathrm{La}_{2} \mathrm{O}_{3}$ disk was made by compressing the mixture of $\mathrm{La}_{2} \mathrm{O}_{3}(10 \%)$ and $\mathrm{KBr}$. The catalyst disk was mounted in a quartz holder within the IR cell connecting to the gas handling system and the $\mathrm{CH}_{4} / \mathrm{O}_{2} / \mathrm{He}$ reaction mixture was admitted into the IR cell at $650{ }^{\circ} \mathrm{C}$. After the reaction for $1 \mathrm{~h}$, the $\mathrm{IR}$ cell was rapidly cooled to $25^{\circ} \mathrm{C}$ and then the IR spectrum was obtained by using FT-IR spectrometer (JASCO 300E) with a resolution of $4.0 \mathrm{~cm}^{-1}$ and 64 scans.

\section{Results and Discussion}

The catalysts prepared in this work showed catalytic activity for the oxidative coupling of methane and major products were $\mathrm{H}_{2}, \mathrm{CO}, \mathrm{CO}_{2}, \mathrm{C}_{2} \mathrm{H}_{4}, \mathrm{C}_{2} \mathrm{H}_{6}$, and $\mathrm{C}_{3}$ hydrocarbons in the temperature range of $650-800{ }^{\circ} \mathrm{C}$. Table 1 shows the methane conversion and product selectivities of catalysts when the reaction mixture was fed over the catalysts at atmospheric pressure. Among the catalysts tested in this work, the $\mathrm{LaFeO}_{3}$ catalyst showed the best $\mathrm{C}_{2}$-yield of $12.0 \%$ with a selectivity of $53.2 \%$ at $750{ }^{\circ} \mathrm{C}$, which is rather appreciable. Figure 3 exhibits variation of methane conversion with reaction temperature in the range of 650$800{ }^{\circ} \mathrm{C}$ and Figure 4 exhibits variations of $\mathrm{C}_{2}$-selectivity with reaction temperature, in which the perovskite catalysts show higher $\mathrm{CH}_{4}$ conversion and $\mathrm{C}_{2}$-selectivity than the $\mathrm{La}_{2} \mathrm{O}_{3}$ catalyst. In the temperature range of $650-800{ }^{\circ} \mathrm{C}, \mathrm{C}_{2}$-yield is $0.9-4.8 \%$ for the $\mathrm{La}_{2} \mathrm{O}_{3}$ catalyst, 5.4-12.0\% for the $\mathrm{LaFeO}_{3}$

Table 1. Methane conversion and product selectivity for oxidative coupling of methane over $\mathrm{LaBO}_{3}$ catalysts

\begin{tabular}{|c|c|c|c|c|c|c|c|c|c|c|}
\hline \multirow{2}{*}{ Catalyst } & \multirow{2}{*}{$\begin{array}{c}\text { BET surface } \\
\text { area }\left(\mathrm{m}^{2} / \mathrm{g}\right)\end{array}$} & \multirow{2}{*}{$\mathrm{T}\left({ }^{\circ} \mathrm{C}\right)$} & \multirow{2}{*}{$\begin{array}{c}\text { Methane } \\
\text { conversion (\%) }\end{array}$} & \multicolumn{6}{|c|}{ Selectivity (\%) } & \multirow{2}{*}{$\mathrm{C}_{2}$ yield } \\
\hline & & & & $\mathrm{H}_{2}$ & $\mathrm{CO}$ & $\mathrm{CO}_{2}$ & $\mathrm{C}_{2} \mathrm{H}_{4}$ & $\mathrm{C}_{2} \mathrm{H}_{6}$ & $\mathrm{C}_{3}^{-}$ & \\
\hline $\mathrm{La}_{2} \mathrm{O}_{3}$ & 5.968 & 750 & 16.3 & 2.1 & 14.3 & 53.1 & 13.3 & 15.9 & 1.3 & 4.8 \\
\hline $\mathrm{La}_{3} \mathrm{FeO}_{3}$ & 3.160 & 750 & 22.5 & 0.5 & 5.6 & 38.2 & 26.2 & 27.0 & 2.5 & 12.0 \\
\hline $\mathrm{LaCoO}_{3}$ & 2.840 & 750 & 23.2 & 1.0 & 3.6 & 45.5 & 21.7 & 26.8 & 1.4 & 11.3 \\
\hline $\mathrm{LaNiO}_{3}$ & 2.697 & 700 & 22.3 & 1.9 & 6.5 & 48.9 & 19.9 & 22.7 & 0.1 & 9.5 \\
\hline
\end{tabular}
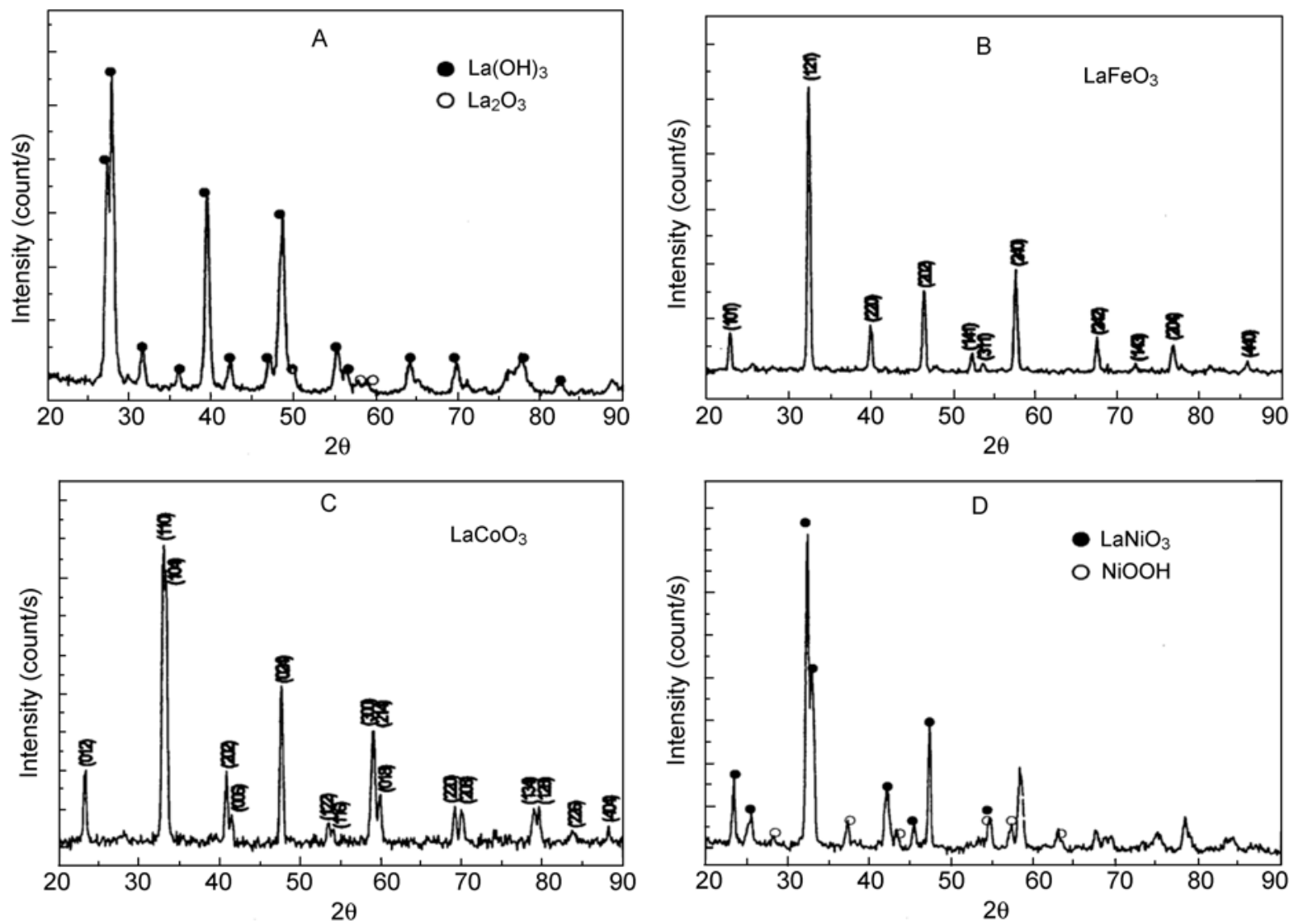

Figure 1. X-ray diffraction patterns of (A) $\mathrm{La}_{2} \mathrm{O}_{3}$, (B) $\mathrm{LaFeO}_{3},(\mathrm{C}) \mathrm{LaCoO}_{3}$, and (D) $\mathrm{LaNiO}_{3}$ catalysts aged in air. $\mathrm{La}(\mathrm{OH})_{3}$ (JCPDS no. 361481); $\mathrm{La}_{2} \mathrm{O}_{3}$ (JCPDS no. 40-1284); $\mathrm{LaFeO}_{3}$ (JCPDS no. 37-1493); $\mathrm{LaCoO}_{3}$ (JCPDS no. 25-1060); $\mathrm{LaNiO}_{3}$ (JCPDS no. 12-0751); NiOOH (JCPDS no. 27-0956). 

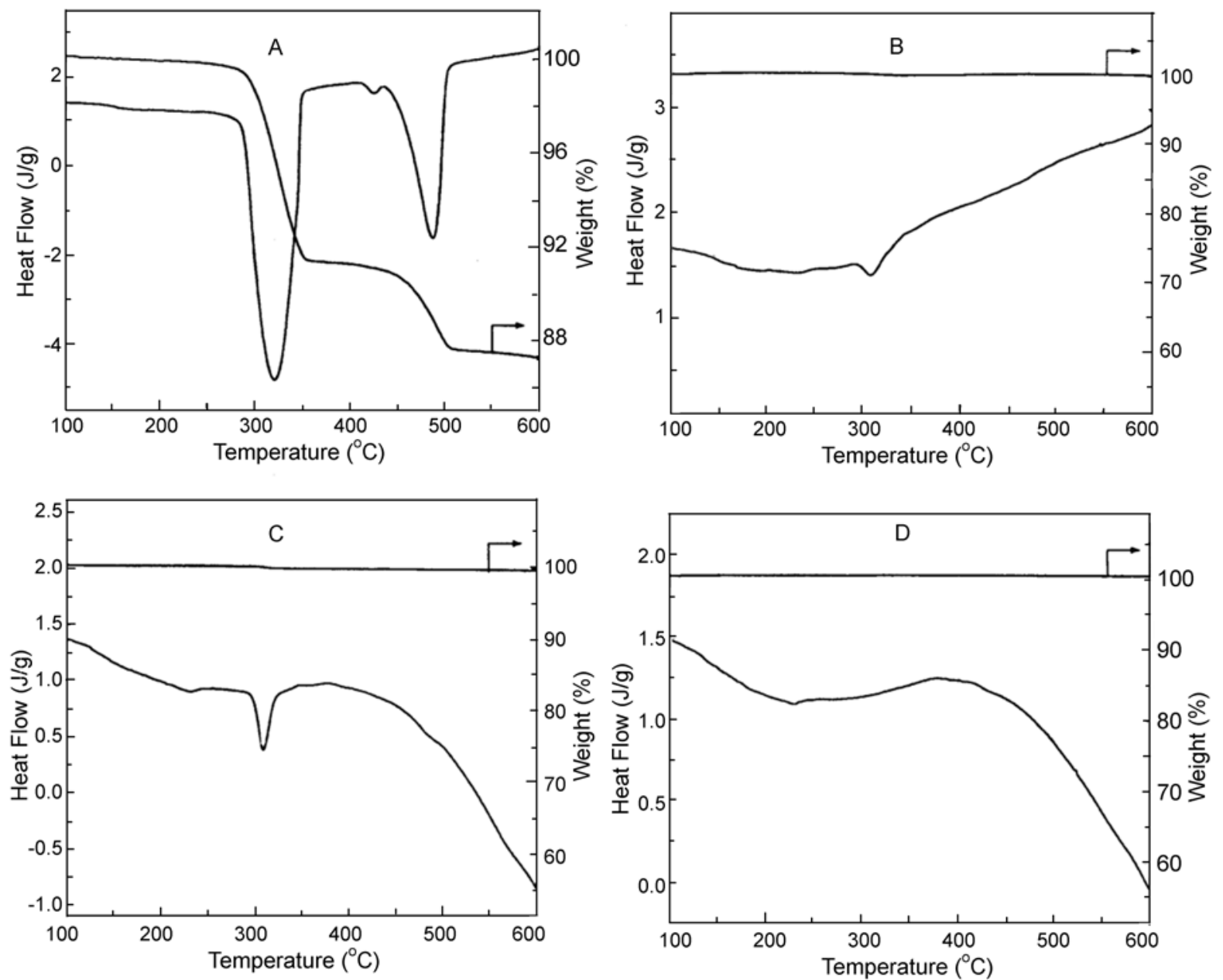

Figure 2. TG and DSC curves of (A) $\mathrm{La}_{2} \mathrm{O}_{3}$, (B) $\mathrm{LaFeO}_{3}$, (C) $\mathrm{LaCoO}_{3}$, and (D) $\mathrm{LaNiO}_{3}$ catalysts aged in air.

catalyst, $6.2-11.3 \%$ for the $\mathrm{LaCoO}_{3}$ catalyst, and $6.1-9.5 \%$ for the $\mathrm{LaNiO}_{3}$ catalyst.

Figure 1 presents the X-ray diffraction patterns of catalysts. The XRD result of $\mathrm{La}_{2} \mathrm{O}_{3}$ catalyst aged in air shows the presence of $\mathrm{La}(\mathrm{OH})_{3}$ as a major crystalline phase, indicating $\mathrm{La}_{2} \mathrm{O}_{3}$ to be hydrated even at room temperature in air. As shown in Figure 2(A), the TG result of $\mathrm{La}_{2} \mathrm{O}_{3}$ catalyst revealed the total weight loss of about $13 \%$ in the temperature range of $100-600{ }^{\circ} \mathrm{C}$, indicating lanthanum hydroxide to be mostly dehydroxylated below $600{ }^{\circ} \mathrm{C}$. The DSC curve of $\mathrm{La}_{2} \mathrm{O}_{3}$ catalyst in Figure 2(A) shows two strong endotherm peaks at $320{ }^{\circ} \mathrm{C}$ and $490{ }^{\circ} \mathrm{C}$. The endotherm at $320^{\circ} \mathrm{C}$ is attributed to the removal of hydroxyl groups from lanthanum hydroxide and the endotherm at 490 ${ }^{\circ} \mathrm{C}$ is attributed to the removal of hydroxyl groups from lanthanum oxyhydroxide $(\mathrm{LaO}(\mathrm{OH})) .{ }^{11}$ Figure 5 exhibits the IR spectra of $\mathrm{La}_{2} \mathrm{O}_{3}$ catalyst after exposure to the $\mathrm{CH}_{4} / \mathrm{O}_{2} / \mathrm{He}$ reaction mixture at $25{ }^{\circ} \mathrm{C}$ and $650{ }^{\circ} \mathrm{C}$. The group of low frequency bands in the range of $1600-1300 \mathrm{~cm}^{-1}$ corresponds to the usual vibration range of carbonate species. ${ }^{12,13}$ According to the in situ FT-IR study on the oxidative coupling of methane over $\mathrm{La}_{2} \mathrm{O}_{3}$ catalyst by Le Van et al., ${ }^{14}$ the dioxomonocarbonate $\left(\mathrm{La}_{2} \mathrm{O}_{2} \mathrm{CO}_{3}\right)$ is formed during the reaction at $650{ }^{\circ} \mathrm{C}$ and its IR bands appear at 1088 and 856 $\mathrm{cm}^{-1}$, which is in good agreement with the present result.

The X-ray diffraction pattern of $\mathrm{LaFeO}_{3}$ catalyst in Figure 1(B) shows monophase perovskite oxide having orthorhombic structure. As shown in Figure 2(B), the DSC curve of $\mathrm{LaFeO}_{3}$ catalyst aged in air shows an endotherm peak at 310 ${ }^{\circ} \mathrm{C}$ and the endotherm is attributable to the removal of hydroxyl groups from lanthanum hydroxide formed by hydration of lanthanum oxide at room temperature in air. The result implies a small amount of lanthanum oxide to be isolated from the perovskite lattice during calcination at 850 ${ }^{\circ} \mathrm{C}$ in air and the isolated lanthanum oxide presumably exists as nanoparticles in the perovskite. Figure 6 presents the IR spectra of $\mathrm{LaFeO}_{3}$ catalyst after exposure to the $\mathrm{CH}_{4} / \mathrm{O}_{2} / \mathrm{He}$ mixture at $25{ }^{\circ} \mathrm{C}$ and $650{ }^{\circ} \mathrm{C}$. The bands ascribing to carbonates are observed in the range of $1600-1300 \mathrm{~cm}^{-1}$ and very weak bands ascribing to $\mathrm{La}_{2} \mathrm{O}_{2} \mathrm{CO}_{3}$ are observed in the range of $1100-800 \mathrm{~cm}^{-1}$. The IR result supports that isolated lanthanum oxide might be produced in the $\mathrm{LaFeO}_{3}$ perovskite by cacination at $850{ }^{\circ} \mathrm{C}$ in air because $\mathrm{La}_{2} \mathrm{O}_{2} \mathrm{CO}_{3}$ should be produced by carbonation of the surface lanthanum oxide during the catalytic reaction at $650{ }^{\circ} \mathrm{C}$.

It may be possible that the $\mathrm{Fe}^{3+}$ ions in $\mathrm{LaFeO}_{3}$ perovskite 


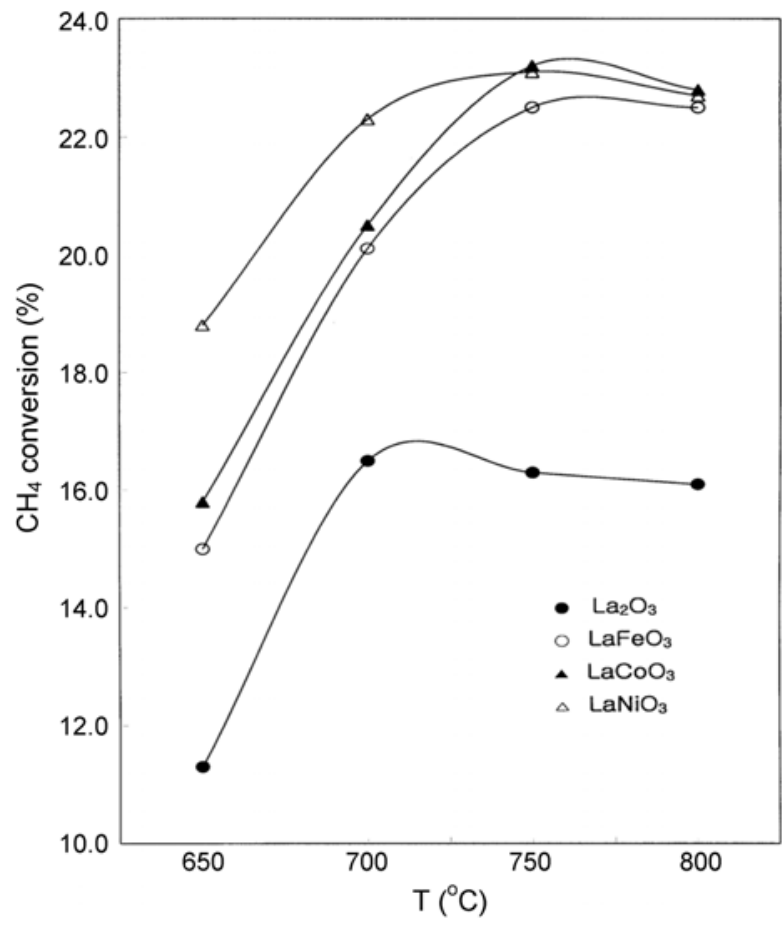

Figure 3. Variation of methane conversion with reaction temperature for $\mathrm{La}_{2} \mathrm{O}_{3}, \mathrm{LaFeO}_{3}, \mathrm{LaCoO}_{3}$, and $\mathrm{LaNiO}_{3}$ catalysts.

are further oxidized to the $\mathrm{Fe}^{4+}$ ions in the presence of gaseous oxygen at high temperatures. When a part of $\mathrm{Fe}^{3+}$ ions converts to higher oxidation state $\left(\mathrm{Fe}^{4+}\right)$, a part of lanthanum ions would be removed from the lattice based on the principle of controlled valency and then it can be represented as $\mathrm{La}_{1-\frac{1}{x}}\left(\mathrm{Fe}_{1-\mathrm{x}}^{3+} \mathrm{Fe}_{\mathrm{x}}^{4+}\right) \mathrm{O}_{3}$. Mizusaki et al. ${ }^{15}$ reported that lanthanum-transition metal perovskite containing an easily oxidizable transition metal cation like $\mathrm{Fe}^{3+}$ shows oxygen-excess structure and p-type conductivity at atmospheric pressure and high temperatures. They suggested that since oxygen-excess composition is assumed to be possible only when the soichiometric composition contains oxygen vacancies that can be filled by a reaction, $\mathrm{Vö}+1 / 2 \mathrm{O}_{2} \rightleftharpoons \mathrm{Oo}+2 \mathrm{~h}$, the perovskite oxide contains a small deficiency of $\mathrm{La}_{2} \mathrm{O}_{3}$ because of the difficulty of controlling the cation ratio precisely, which is agreeable to the present result. It can be assumed that the high valency $\left(\mathrm{Fe}^{4+}\right)$ of iron cations is likely to be converted to the low valency $\left(\mathrm{Fe}^{3+}\right)$ since the $\mathrm{Fe}^{4+}$ is unstable, which results in the formation of oxygen vacancies in the perovskite, representing as

$$
\mathrm{La}_{1-\frac{1}{3} \mathrm{x}}\left(\mathrm{Fe}_{1-\mathrm{x}+\delta}^{3+} \mathrm{Fe}_{\mathrm{x}-\delta}^{4+}\right) \mathrm{O}_{3-\frac{1}{2} \delta} .
$$

The X-ray diffraction pattern in Figure 1(C) shows monophase $\mathrm{LaCoO}_{3}$ perovskite having rhombohedral structure. In Figure 2(C), the DSC curve of $\mathrm{LaCoO}_{3}$ catalyst aged in air shows an endotherm peak at $310{ }^{\circ} \mathrm{C}$, indicating the presence of lanthanum hydroxide. A small amount of lanthanum oxide might be isolated from the $\mathrm{LaCoO}_{3}$

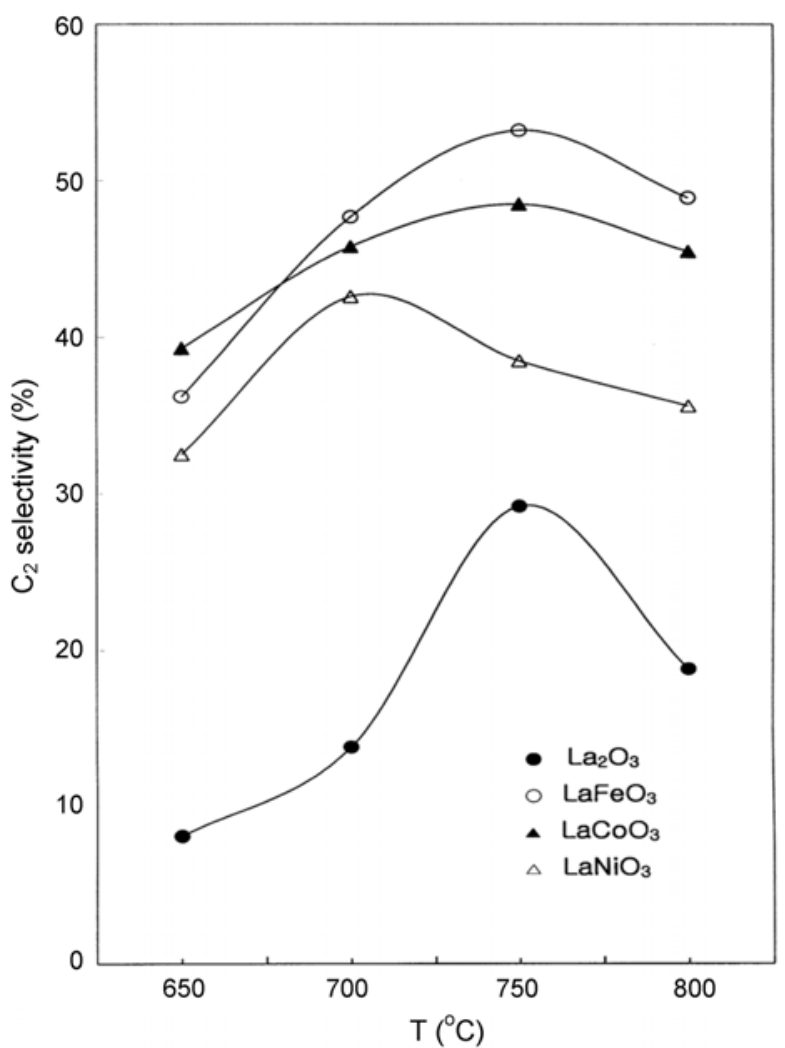

Figure 4. Variation of $\mathrm{C}_{2}$-selectivity with reaction temperature for $\mathrm{La}_{2} \mathrm{O}_{3}, \mathrm{LaFeO}_{3}, \mathrm{LaCoO}_{3}$, and $\mathrm{LaNiO}_{3}$ catalysts.

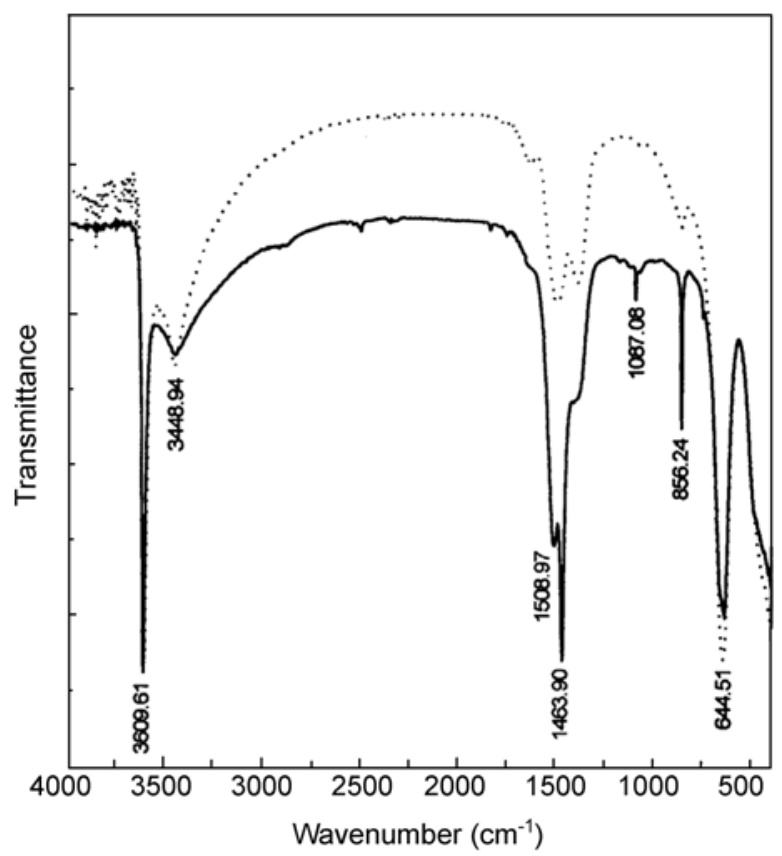

Figure 5. FT-IR spectra of $\mathrm{La}_{2} \mathrm{O}_{3}$ catalyst after exposure to a $\mathrm{CH}_{4} /$ $\mathrm{O}_{2} / \mathrm{He}$ mixture at $25^{\circ} \mathrm{C}$ (dotted line) and $650{ }^{\circ} \mathrm{C}$ (solid line).

perovskite lattice by calcination at $850{ }^{\circ} \mathrm{C}$ in air. Though many authors have considered the $\mathrm{LaCoO}_{3}$ system to be stoichiometric, several investigators pointed out the perovskite to be essentially nonstoichiometric. ${ }^{16,17}$ O'Connel et 


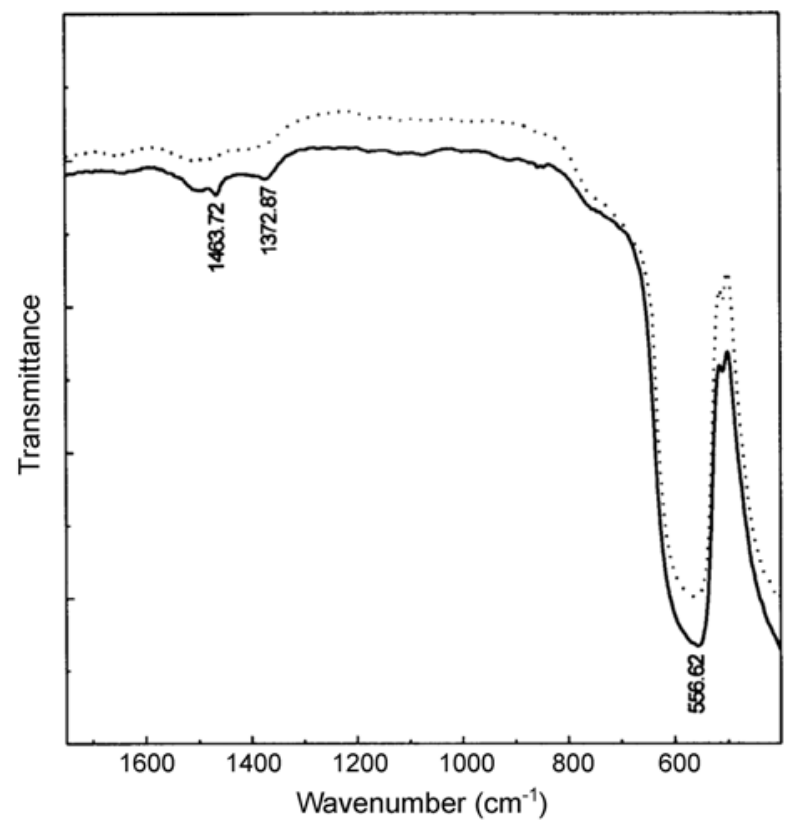

Figure 6. FT-IR spectra of $\mathrm{LaFeO}_{3}$ catalyst after exposure to a $\mathrm{CH}_{4} / \mathrm{O}_{2} / \mathrm{He}$ mixture at $25{ }^{\circ} \mathrm{C}$ (dotted line) and $650{ }^{\circ} \mathrm{C}$ (solid line).

$a l{ }^{16}$ found the isolated lanthanum oxide in the $\mathrm{LaCoO}_{3}$ perovskite when the perovskite is prepared by precipitation from mixed nitrate solutions ( $\mathrm{La}:$ Co atomic ratio of $1: 1$ ) using tetraethyl ammonium hydroxide and followed by calcination at $800{ }^{\circ} \mathrm{C}$ in $\mathrm{He}$. As in the case of $\mathrm{LaFeO}_{3}$ perovskite, when the $\mathrm{Co}^{3+}$ ions partly convert to the $\mathrm{Co}^{4+}$, lanthanum-deficient $\mathrm{LaCoO}_{3}$ perovskite can be formed. The $\mathrm{Co}^{4+}$ cations is likely to be converted to the $\mathrm{Co}^{3+}$ since the $\mathrm{Co}^{4+}$ is unstable, resulting in the formation of oxygen vacancies in the perovskite. Then the perovskite can be written as

$$
\mathrm{La}_{1-\frac{1}{3} \mathrm{x}}\left(\mathrm{Co}_{1-\mathrm{x}+\delta}^{3+} \mathrm{Co}_{\mathrm{x}-\delta}^{4+}\right) \mathrm{O}_{3-\frac{1}{2} \delta}
$$

On the other hand, the $\mathrm{LaNiO}_{3}$ catalyst showed different aspects from the $\mathrm{LaFeO}_{3}$ and $\mathrm{LaCoO}_{3}$ catalysts. In Figure 1(D), the XRD result of $\mathrm{LaNiO}_{3}$ catalyst aged in air shows the presence of nickel oxyhydroxide $(\mathrm{NiOOH})$. It can be assumed that when the $\mathrm{LaNiO}_{3}$ perovskite is calcined in air at $850{ }^{\circ} \mathrm{C}$, some nickel oxide is removed from the lattice and then, the isolated nickel oxide reacts with water vapor in air to form the nickel oxyhydroxide. In Figure 2(D), the DSC curve of $\mathrm{LaNiO}_{3}$ catalyst aged in air shows a very weak endotherm peak at $230{ }^{\circ} \mathrm{C}$ and the endotherm is ascribed to dehydroylation of nickel hydroxide. It is believed from the result that the nickel oxyhydroxide $\left(\mathrm{Ni}^{3+}-\mathrm{OOH}\right)$ contains a small amount of nickel hydroxide $\left(\mathrm{Ni}^{2+}-(\mathrm{OH})_{2}\right)$. When some nickel oxide is isolated from the $\mathrm{LaNiO}_{3}$ lattice, the perovskite would be an oxygen-deficient oxide representing as $\mathrm{La}_{1} \mathrm{Ni}_{1-\mathrm{x}} \mathrm{O}_{3-\mathrm{x}}$.

In this context, it is worth noting that when $\mathrm{LaBO}_{3}$ perovskites are calcined in air at $850{ }^{\circ} \mathrm{C}$, lanthanum- deficiencies are created in the $\mathrm{LaFeO}_{3}$ or $\mathrm{LaCoO}_{3}$ perovskite lattice while transition metal-deficiencies are created in the $\mathrm{LaNiO}_{3}$ perovskite lattice, and the type of metal defects created in the perovskite is considered to depend on the oxidizability of transition metal ion $\left(\mathrm{B}^{3+}\right)$ in air at high temperatures.

As described above, the present perovskite catalysts contain oxygen vacancies. The nature of active sites in metal oxide catalyst for the oxidative coupling of methane is not yet fully understood. However, it is generally accepted that less electophilic oxygen species adsorbed on oxygen vacancy sites or highly basic surface lattice oxygen activate methane to generate methyl radicals and the resulting methyl radicals are coupled to form ethane in gas phase. ${ }^{18}$ According to Domen et al., ${ }^{19}$ when gaseous oxygen is adsorbed on oxygen vacancies, super oxide species $\left(\mathrm{O}_{2}{ }^{-}\right)$are formed immediately, successively converted into $\mathrm{O}_{2}{ }^{2-}, \mathrm{O}^{-}$, and finally into $\mathrm{O}^{2-}$ (latt). ${ }^{19}$ Many investigators have suggested that in the oxidative methane coupling reaction over perovskite oxide catalysts, the existence of strongly bonded oxygen on the surface is effective to obtain more selectively $\mathrm{C}_{2}$-hydrocarbons from methane, in contrast to the weakly bonded oxygen necessary for deep oxidation of hydrocarbons. ${ }^{20-22}$ Namely, weakly adsorbed molecular oxygen such as $\mathrm{O}_{2}{ }^{-}$and $\mathrm{O}_{2}{ }^{2-}$ favors the formations of carbon oxides and less electrophilic oxygen species such as $\mathrm{O}^{-}$and $\mathrm{O}^{2-}$ enhance the formation of methyl radicals leading to $\mathrm{C}_{2}$ hydrocarbons. All these oxygen species adsorbed on the surface might exist in an equilibrium state and the concentration of less electrophilic oxygen species on the surface might depend on the temperature and oxygen partial pressure.

In this work, the differences in $\mathrm{C}_{2}$-selectivity of $\mathrm{LaFeO}_{3}$, $\mathrm{LaCoO}_{3}$, and $\mathrm{LaNiO}_{3}$ catalysts seems to be closely related to their defect structures rather than their textual properties because their specific surface areas do not differ significantly as listed in Table $1 . \mathrm{LaNiO}_{3}$ is known to be easily reduced by high temperature sintering ${ }^{23}$ and the XRD reslut in Figure 1(D) reveals that the isolated nickel oxyhydroxide exists as a XRD detectable amount on the $\mathrm{LaNiO}_{3}$ surface. Therefore, the $\mathrm{LaNiO}_{3}$ perovskite can be assumed to contain more oxygen vacancies compared with the $\mathrm{LaFeO}_{3}$ and $\mathrm{LaCoO}_{3}$ perovskites. Since a high surface concentration of oxygen anion vacancies favours oxygen adsorption and transformation into less electrophilic oxygen species, ${ }^{22}$ the $\mathrm{LaNiO}_{3}$ catalyst is expected to show higher $\mathrm{C}_{2}$-selectivity than the other catalysts, but its $\mathrm{C}_{2}$-selectivity is lower than the other perovskite catalysts as shown in Figure 4. Its lower $\mathrm{C}_{2}$-selectivity seems to be due to the presence of isolated nickel oxide existing on the surface as an XRD detectable amount because nickel oxide is inactive for the oxidative coupling of methane.

Consequently, oxygen anion vacancies can be formed in the $\mathrm{LaBO}_{3}$ perovskites by calcination at high temperatures in air without altervalent cation doping. A mixture of isolated lanthanum oxide and lanthanum-deficient $\mathrm{LaFeO}_{3}$ or $\mathrm{LaCoO}_{3}$ perovskite shows higher $\mathrm{C}_{2}$-selectivity than a 
mixture of isolated nickel oxide and $\mathrm{LaNiO}_{3}$ perovskite for the oxidative coupling of methane. Although it is clear that oxygen anion vacancies play important role in the oxidative coupling of methane, the influence of isolated lanthanum oxide or isolated transition metal oxide on the nature of catalyst cannot be excluded. The formation of isolated lanthanum oxide or isolated transition metal oxide in the $\mathrm{LaBO}_{3}$ catalysts under the reaction conditions and its role in the catalytic reaction require further research to be understood. It is necessary to study the ionic conductivity of perovskite in conjunction with its catalytic behavior above $700{ }^{\circ} \mathrm{C}$ because the mobility of oxygen ions in the perovskite is considered to relate to the formation of less electrophilic oxygen species on the surface and the study is currently in progress.

Acknowledgements. This work was supported by Maeji Institute of Academic Research of Yonsei University in 2002 and National R \& D Project of Nano-science and Technology (grant No. M1-0203-00-0003). Prof. Y.-R. Kim thanks for a National Research Laboratory (grant No. M10302-00-0027) program.

\section{References}

1. Oyama, S. T. In Heterogeneous Hydrocarbon Oxidation; Warren, B. K., Ed.; American Chemical Society: Washington DC, 1996; p 2.

2. Lee, J. W.; Lee, J. K.; Cho, S. K.; Jung, J. S.; Lee, S. H. Bull. Korean Chem. Soc. 2004, 25, 573.

3. Hugill, J. A.; Tillemans, F. W. A.; Dijkstra, J. W.; Spoelstra, S.
Appl. Thermal Engineering 2005, 25, 1259.

4. Seiyama, T. In Properties and Applications of Perovskite-type Oxides; Tejuca, L. G.; Fierro, J. L. G., Eds.; Marcel Dekker Inc.: New York, 1993; p 215.

5. Dissanyake, D.; Kharas, K. C. C.; Lunsford, J. H.; Rosynek, M. P. J. Catal. 1993, 139, 652.

6. Takawa, T.; Imai, H. J. Chem. Soc. Faraday Trans. 1 1988, 84, 923.

7. Spinicci, R.; Tofanari, A.; Delmastro, A.; Mazza, D.; Ronchetti, S. Mat. Chem. Phys. 2002, 76, 20.

8. Spinicci, R.; Martini, P.; DeRossi, S.; Faticanti, M.; Porta, P. $J$. Mole. Catal. A: Chemical 2001, 176, 253.

9. Akin, F. T.; Lin, J. Y. S. J. Mater. Sci. 2004, 231, 133.

10. Peri, J. B. In Catalysis Science and Technology; Anderson, J. R.; Boudart, M., Eds.; Springer-Verlag: New York, 1984; Vol. 5, p 171.

11. Bernal, S.; Botana, F. J.; Garcia, R.; Rodriguez-Izquierdo, J. M. Reactivity of Solids 1987, 4, 23.

12. Lacombe, S.; Zanthoff, H.; Mirodatos, C. J. Catal. 1995, 155, 106.

13. Taylor, R. P.; Schrader, G. L. Ind. Eng. Res. 1991, 30, 1016.

14. Le Van, T.; Che, M.; Tatibouet, H.; Kermarec, M. J. Catal. 1993, $142,18$.

15. Mizusaki, J.; Sosamoto, T.; Cannon, W. R.; Bowen, H. K. J. Am. Ceram. Soc. 1982, 65, 363.

16. O'Connell, M.; Norman, A. K.; Huttermann, C. F.; Morris, M. A. Catalysis Today 1999, 47, 123.

17. Wu, Y.; Yu, T.; Dou, B. S.; Wang, X.; Xie, X.-F.; Yu, Z. L.; Fan, S. R.; Fan, Z. R.; Wang, L. C. J. Catal. 1989, 120, 88

18. Lunsford, J. H. Angew. Chem. 1995, 34, 970.

19. Li, K.; Domen, K.; Maruya, K.; Onishi, T. J. Am. Chem. Soc. 1989, $111,7683$.

20. Nitadori, T.; Misono, M. J. Catal. 1985, 93, 459.

21. France, J. E.; Shamsi, A.; Ahsam, M. Q. Energy and Fuels 1988 , $2,235$.

22. Borchert, H.; Baerns, M. J. Catal. 1997, 168, 315.

23. Fierro, J. L. G.; Tascn, J. M. D.; Tejuca, L. G J. Catal. 1985, 93, 83. 